\title{
An assessment of sensitivity biomarkers for urinary cadmium burden
}

\author{
Yuting Li ${ }^{1}$, Hongmei Wang ${ }^{2 *}$, Jie Yu', Qiong Yan ${ }^{1}$, Honggang Hu${ }^{1}$, Lishu Zhang ${ }^{1}$, Tian Tian ${ }^{1}$, Xianglei Peng ${ }^{1}$, \\ Shuo Yang ${ }^{1}$ and Shen $\mathrm{Ke}^{1 *}$
}

\begin{abstract}
Background: Excess cadmium (Cd) intake poses a general risk to health and to the kidneys in particular. Among indices of renal dysfunction under $C d$ burden measures are the urinary $N$-acetyl- $\beta$-D-glucosidase (UNAG) and urinary $\beta_{2}$-microglobulin $\left(U \beta_{2}-M G\right)$ enzymes. However, the end-pointed values and the $\mathrm{Cd}$ burden threshold remain controversial because the scopes fluctuate widely.

Methods: To ascertain the clinical benchmark dose of urinary Cd (UCd) burden for renal dysfunction, 1595 residents near a $\mathrm{Cd}$ site were surveyed. Urine was sampled and assayed. A benchmark dose low (BMDL) was obtained by fitting UCd levels and index levels.
\end{abstract}

Results: We found that over $50 \%$ of the subjects were suffering from Cd exposure as their UCd levels far exceeded the national standard threshold of $5.000 \mathrm{\mu g} / \mathrm{g}$ creatinine (cr). Further analysis indicated that $U \beta_{2}-M G$ was more sensitive than UNAG for renal dysfunction. The BMDL for $\mathrm{UCd}$ was estimated as $3.486 \mathrm{U} / \mathrm{g} \mathrm{cr}$ (male, where $\mathrm{U}$ is unit of enzyme) and $2.998 \mathrm{U} / \mathrm{g} \mathrm{cr}$ (female) for UNAG. The BMDL for $\mathrm{U} \beta_{2}-\mathrm{MG}$, which is released into urine from glomerulus after $\mathrm{Cd}$ exposure, was found to be $2.506 \mu \mathrm{g} / \mathrm{g} \mathrm{cr}$ (male, where $\mu \mathrm{g}$ is the unit of microglobulin) and $2.236 \mu \mathrm{g} / \mathrm{g} \mathrm{cr}$ (female).

Conclusions: $U \beta_{2}-M G$ is recommended as the sensitivity index for renal dysfunction, with $2.2 \mu \mathrm{g} / \mathrm{g} \mathrm{cr}$ as the threshold for clinical diagnosis. Our findings suggest that $U \beta_{2}-M G$ is the better biomarker for exposure to $C d$.

Keywords: Urinary cadmium, Urinary N-acetyl- $\beta$-D-glucosidase (UNAG), Urinary $\beta_{2}$-microglobulin (U $\left.\beta_{2}-M G\right)$, Benchmark dose, Renal dysfunction

\section{Background}

Cadmium $(\mathrm{Cd})$ in the environment enters organisms via the atmosphere, drinking water, and contaminated soil and food [1]. Excess Cd exposure is harmful to health [2, 3]. The well-known case of the Itai-Itai disease in Japan was the most severe stage of long-term Cd exposure [1]. Many organs are damaged by excess Cd burden,

\footnotetext{
*Correspondence: wanghmxj@163.com; 8296@bjtu.edu.cn

${ }^{2}$ State Key Laboratory of Environmental Criteria and Risk Assessment, Department of Environment and Health, Chinese Research Academy of Environmental Sciences, Beijing 100012, PR China

${ }^{1}$ Department of Life Science and Bioengineering, School of Science, Beijing Jiaotong University, No.3, Shangyuan Village, Haidian District, Beijing 100044, China
}

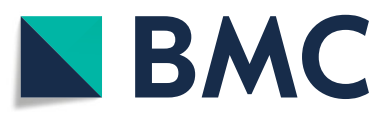

( The Author(s). 2020 Open Access This article is licensed under a Creative Commons Attribution 4.0 International License, which permits use, sharing, adaptation, distribution and reproduction in any medium or format, as long as you give appropriate credit to the original author(s) and the source, provide a link to the Creative Commons licence, and indicate if changes were made. The images or other third party material in this article are included in the article's Creative Commons licence, unless indicated otherwise in a credit line to the material. If material is not included in the article's Creative Commons licence and your intended use is not permitted by statutory regulation or exceeds the permitted use, you will need to obtain permission directly from the copyright holder. To view a copy of this licence, visit http://creativecommons.org/licenses/by/4.0/. The Creative Commons Public Domain Dedication waiver (http://creativecommons.org/publicdomain/zero/1.0/) applies to the data made available in this article, unless otherwise stated in a credit line to the data. resulting in defective bone formation, including osteoporosis $[4,5]$, and some cancers $[6,7]$. The kidney is an important organ that suffers damage from $\mathrm{Cd}$ exposure, as reported by previous studies $[8,9]$. This view has been further supported by more recent research, which has also recommended that the kidney is to be considered an early-stage target of $\mathrm{Cd}[10,11]$.

A range of factors (including age, years of exposure, and gender) that affect the relationship between $\mathrm{Cd}$ burden and the prevalence of kidney dysfunction have been determined to contribute the Cd threshold [12-14], but the interaction mechanism remains unclear. A range of biomarkers of renal dysfunction have been used 
diagnostically in this context $[15,16]$, including urinary $\mathrm{N}$-acetyl- $\beta$-D-glucosidase (UNAG), urinary $\beta_{2}$-microglobulin $\left(\mathrm{U} \beta_{2}-\mathrm{MG}\right)$, and urinary retinol binding protein (URBP) [17-19]. These three are likely valid biomarkers due to their origin in the renal tubules or in glomeruli breakage under urinary (UCd) pressure [20-22]. However, it is not yet clear which is the most sensitive to $\mathrm{UCd}$.

The threshold concentrations of UCd used in different countries varies due to the differences in subjects and models. The benchmark dose (BMD) is the dose that can increase an effect to a specific response level. The value of BMD can reflect the dose-response relationship and the quality of the data used. The benchmark dose method is a new method to determine the reference dose. This method can explain and develop the dose-response relationship from the perspective of mathematical statistics, and has become an effective method for toxicological science to determine the reference dose. No observed adverse effect level (NOAEL) refers to the highest dose or concentration of an exogenous chemical that does not cause detectable harmful effects in the body through experiments and observations under prescribed exposure conditions. This method ignores the early effects of adverse reactions. When the health threshold of heavy metals is being studied, the benchmark dose (BMD) method can make up for the deficiencies of the No Observed Adverse Effect Level (NOAEL) method. The BMD of UCd obtained from $\mathrm{U}_{2}$-MG ranged from 2.08 to $3.80 \mu \mathrm{g} / \mathrm{g}$ creatinine $(\mathrm{cr})$ at one site, and at another, the BMD varied from 0.99 to $3.34 \mu \mathrm{g} / \mathrm{g}$ cr [23]. Another study found a BMD of UCd $1.9 \mu \mathrm{g} / \mathrm{g}$ cr measured by $\mathrm{U} \beta_{2}$-MG, from 81 samples [22]. It is speculated that sample size might interfere with UCd threshold levels.

With greater insight into the sensitivity of the biomarkers, the data for the UCd scope was to vary widely, as did the renal dysfunction indexes. For example, the estimated BMD low (BMDL) of UCd was $6.9 \mu \mathrm{g} / \mathrm{g}$ cr (where $\mu \mathrm{g}$ is the unit of microglobulin) for $\mathrm{U} \beta_{2}-\mathrm{MG}$ and $4.4 \mathrm{U} / \mathrm{g}$ cr (where $\mathrm{U}$ is unit of the enzyme) for UNAG in males and $8.1 \mu \mathrm{g} / \mathrm{g}$ cr for $\mathrm{U} \beta_{2}$-MG and $6.1 \mathrm{U} / \mathrm{g}$ cr for UNAG in females [24]. In addition, the BMDs for UCd for $\beta_{2}$-MG and UNAG were $2.09 \mu \mathrm{g} / \mathrm{g}$ cr and $1.80 \mathrm{U} / \mathrm{g} \mathrm{cr}$ in males and $2.10 \mu \mathrm{g} / \mathrm{g} \mathrm{cr}$ and $2.31 \mathrm{U} / \mathrm{g} \mathrm{cr}$ in females, respectively [25].

To obtain an early diagnosis and prevention for $\mathrm{Cd}$ exposure, it is essential to establish the threshold for the sensitivity index for clinical detection. However, there is still little quantitative analysis of the changes in $\mathrm{UCd}$ $\mathrm{BMDs}$ for the occupationally exposed, who have high $\mathrm{Cd}$ exposure levels, in comparison to those who are not occupationally exposed. This study, therefore, assessed the UCd BMDs by sampling people living with high levels of $\mathrm{Cd}$ exposure.

\section{Methods}

\section{Survey location and subjects}

Xiaogan in Hubei province, China, was selected as the $\mathrm{Cd}$ exposure site for this study [26]. Smelting has been performed here for nearly three decades. The residents of 20 nearby villages could conceivably have been exposed to $\mathrm{Cd}$ released directly or indirectly from the smelting. The average age of the participants in this study was more than 50 years, and most had exposure times of more than 25 years. Patients with chronic or endocrine diseases, such as diabetes or thyroid, liver, or kidney damage, were excluded. Some participants had had long-term exposure through their employment.

Participants with missing data, including demographic information, and those with urinary cr lower than $0.3 \mathrm{~g} /$ $\mathrm{L}$ or above $3.0 \mathrm{~g} / \mathrm{L}$, were not factored in. A total of 1595 participants, most of who were engaged in agriculture, were observed in this study. In all, $36.8 \%$ (587) were male and $63.2 \%$ (1008) were female. All subjects consumed locally produced rice and vegetables and drank municipal water. Questionnaires were administered after that informed consent was signed. This study was approved by the Ethics Committee of the School of Science at Beijing Jiaotong University and of the No. 1 People's Hospital of Xiaogan. The study was carried out by uniformly trained investigators.

\section{Sampling and testing}

The containers and utensils used for urine collection and transportation were thoroughly washed, soaked with dilute nitric acid for $12 \mathrm{~h}$, and rinsed with deionized water before use. Morning urine samples of the 1595 subjects were collected and then stored frozen at $-20^{\circ} \mathrm{C}$ for analysis.

UNAG and $\mathrm{U} \beta_{2}-\mathrm{MG}$ in urine were measured as indexes of renal dysfunction. The UCd concentrations were determined using graphite furnace atomic absorption spectrometry with peak area evaluation described in previous studies. The UNAG concentrations were measured using the spectrophotometer colorimetric method, and the $\mathrm{U} \beta_{2}$-MG concentrations were measured using radioimmunoassay. All urine samples were acidified with concentrated nitric acid to determine the different UCd concentrations. Urinary cr concentrations were assessed with picric acid with protein method. All measurement techniques were conducted as described elsewhere [27]. All samples were tested using parallel samples, and the detection value was less than $5 \%$. According to the Guidelines for the Diagnosis and Treatment of Heavy Metal Pollution of China (Trial) in 2010 (GOMOHC) and the Minister of Health of the People's Republic of China (MOHC) in 1998 [28, 29], the threshold values for UNAG and $\mathrm{U} \beta_{2}-\mathrm{MG}$ are $17 \mathrm{U} / \mathrm{g}$ cr and $1000 \mu \mathrm{g} / \mathrm{g} \mathrm{cr}$, 
respectively. All urinary indexes were adjusted for the cr concentrations, and all were expressed as $\mu \mathrm{g} / \mathrm{g} \mathrm{cr}$.

\section{Statistical analysis}

Statistical analysis and hypothesis testing on data were performed by SPSS 22.0. Two independent sample $t$ tests and the non-parametric Mann-Whitney test were used to compare the means. The UCd levels were transformed by logarithm $(\log 10)$ to obtain variables that were approximately normally distributed and to meet the linear model requirement before they were detected by Pearson correlation analysis. Abnormalities in health effects were tested using the $x^{2}$ test. The correlations between UCd burden and exposure factors (including age, years of exposure, and gender) were assessed using a multiple linear regression model $(\alpha=0.05)$, and $p$-values less than 0.05 were considered to indicate statistically significant differences. Analysis of variance, the $x^{2}$ test, and Spearman rank correlation were used to detect significant differences in the relationship between the UCd burden and the renal dysfunction index.

\section{BMD computation}

The BMDs of UCd and the $95 \%$ lower confidence limits (BMDLs) in relation to renal effects were deduced by Benchmark Dose Software (US Environmental Protection Agency, version 2.7.0.4). The BMDL was set in relation to a health risk assessment. The results were crossvalidated using four models (the gamma, logistic, loglogistic, and log-profit models). The Benchmark Dose Technical Guidance asserts that the lower the Akaike information criterion (AIC) value, the better optimized the model derived, and a similar principle holds for $x^{2}$ values. The small undulation in $\chi^{2}$ values is the counterpart to a lower deviation in experimental results, meaning a better-fitting result. Here the lowest AIC value was obtained by logistic model, so it was used to calculate the UCd threshold concentration, on the condition that the benchmark dose response (BMR) was set as an extra $10 \%$ risk. Where $p \geq 0.05$, the results were defined as the endpoint BMD value, following the Benchmark Dose Technical Guidance [30].

\section{Results}

\section{Demographic information}

In all, 1595 (587 male and 1008 female) participants from twenty villages near Xiaogan were surveyed, and the demographic character was shown (Table 1). The average participant age was $63.89( \pm 8.4)$ years old (the female average was 65.01 years old and the male average was 63.24). The UCd concentration was in the scope of 0.030 to $20.279 \mu \mathrm{g} / \mathrm{g}$ cr (Table 1 ). The maximum geometric mean of the male UCd levels $(4.726 \mu \mathrm{g} / \mathrm{g} \mathrm{cr})$ was lower than that of females $(5.393 \mu \mathrm{g} / \mathrm{g} \mathrm{cr})$. The average UCd of the total population was estimated to be $4.507 \mu \mathrm{g} / \mathrm{g}$ cr. An increasing trend was shown between male and female UCd levels. The geometric mean value for UCd among females was higher than that for males $(p<0.05)$. The mean UNAG value among the males $(11.790 \mathrm{U} / \mathrm{g} \mathrm{cr})$ was different from that for females $(11.817 \mathrm{U} / \mathrm{g} \mathrm{cr})$. The average male $\mathrm{U} \beta_{2}$-MG level was $611.63 \mu \mathrm{g} / \mathrm{g} \mathrm{cr}$, and the female average was $643.10 \mu \mathrm{g} / \mathrm{g}$ cr (Table 1). The mean UNAG $(11.807 \mathrm{U} / \mathrm{g} \mathrm{cr})$ for all subjects was lower than the national standard threshold

Table 1 Characteristics of the population entailed in the study

\begin{tabular}{llllllllll}
\hline Gender & Age & No. & Age & UCd & Range & UNAG & Range & U $\beta_{2}$-MG & Range \\
\hline Male & {$[50,60]$} & 188 & $56.00(2.984)$ & $4.387(3.122)$ & $0.046 \sim 18.397$ & $12.193(9.176)$ & $1.160 \sim 46.516$ & $634.34(527.703)$ & $7.83 \sim 2497.43$ \\
& $(60,70]$ & 263 & $65.24(2.655)$ & $4.493(3.878)$ & $0.044 \sim 17.859$ & $11.353(9.414)$ & $0.631 \sim 40.485$ & $594.95(524.558)$ & $4.30 \sim 2518.24$ \\
& $(70,80]$ & 104 & $74.88(2.720)$ & $4.560(4.075)$ & $0.046 \sim 18.397$ & $11.010(9.147)$ & $0.838 \sim 43.640$ & $615.05(568.154)$ & $10.30 \sim 2573.07$ \\
& $(80,90]$ & 32 & $84.06(2.449)$ & $4.726(5.105)$ & $0.500 \sim 18.662$ & $16.493(11.883)$ & $3.899 \sim 66.157$ & $608.48(536.842)$ & $75.79 \sim 2943.91$ \\
& Total & 587 & $65.01(8.408)$ & $4.483(3.786)$ & $0.044 \sim 18.925$ & $11.790(9.527)$ & $0.631 \sim 66.157$ & $611.63(535.198)$ & $4.30 \sim 2943.91$ \\
Female & {$[50,60]$} & 401 & $55.20(3.297)$ & $4.408(3.878)$ & $0.085 \sim 20.279$ & $11.581(8.794)$ & $0.435 \sim 41.642$ & $615.36(492.337)$ & $4.09 \sim 2552.80$ \\
& $(60,70]$ & 424 & $65.06(2.625)$ & $4.494(3.804)$ & $0.030 \sim 18.905$ & $12.001(9.698)$ & $0.505 \sim 46.664$ & $652.13(575.076)$ & $12.37 \sim 2614.23$ \\
& $(70,80]$ & 153 & $75.17(2.837)$ & $4.748(4.162)$ & $0.320 \sim 19.694$ & $12.240(10.138)$ & $0.921 \sim 47.250$ & $678.00(604.090)$ & $37.78 \sim 2828.72$ \\
& $(80,90]$ & 30 & $84.13(2.872)$ & $5.393(3.889)$ & $0.884 \sim 16.330$ & $10.400(10.563)$ & $0.411 \sim 50.105$ & $727.37(648.506)$ & $42.09 \sim 2965.66$ \\
& Total & 1008 & $63.24(8.392)$ & $4.522(3.896)$ & $0.030 \sim 20.279$ & $11.817(9.462)$ & $0.411 \sim 50.105$ & $643.10(553.120)$ & $4.09 \sim 2965.66$ \\
Total & {$[50,60]$} & 589 & $55.45(3.222)$ & $4.401(3.657)$ & $0.046 \sim 20.279$ & $11.773(8.923)$ & $0.435 \sim 46.516$ & $621.35(504.178)$ & $4.09 \sim 2552.80$ \\
& $(60,70]$ & 687 & $65.13(2.638)$ & $4.494(3.833)$ & $0.030 \sim 18.905$ & $11.749(9.595)$ & $0.505 \sim 46.664$ & $629.62(557.553)$ & $4.30 \sim 2614.23$ \\
& $(70,80]$ & 257 & $75.05(2.794)$ & $4.671(4.127)$ & $0.095 \sim 19.694$ & $11.726(9.773)$ & $0.838 \sim 47.250$ & $651.78(589.980)$ & $10.30 \sim 2828.72$ \\
& $(80,90]$ & 62 & $84.10(2.662)$ & $5.038(4.558)$ & $0.500 \sim 18.662$ & $13.194(11.527)$ & $0.411 \sim 66.157$ & $663.36(600.832)$ & $42.09 \sim 2965.66$ \\
& Total & 1595 & $63.89(8.442)$ & $4.507(3.856)$ & $0.030 \sim 20.279$ & $11.807(9.486)$ & $0.411 \sim 66.157$ & $631.33(546.768)$ & $4.09 \sim 2965.66$ \\
\hline
\end{tabular}

The units of the above indicators: Age (years), UCd $\left(\mu \mathrm{g} / \mathrm{g} \mathrm{cr}\right.$ ), UNAG (U/g cr) and U $\beta_{2}-\mathrm{MG}(\mu \mathrm{g} / \mathrm{g} \mathrm{cr})$. Age is expressed as the arithmetic mean (standard deviation): UCd, UNAG and $U \beta_{2}-M G$ are expressed as geometric mean (geometric standard deviation) 
value $(17 \mathrm{U} / \mathrm{g} \mathrm{cr})(p<0.05)$ as found by MOHC in 1998 , and the $\mathrm{U} \beta_{2}$-MG mean $(631.33 \mu \mathrm{g} / \mathrm{g} \mathrm{cr})$ was lower than $1000 \mu \mathrm{g} / \mathrm{g}$ cr $(p<0.05)$. Further analysis revealed that the maximum value found for UNAG was 3.89 times the national standard threshold value, and the $\mathrm{U} \beta_{2}$-MG value was 2.97 times the standard. There was a large undulation shown in the scope of UNAG, which varied from 0.411 to $66.157 \mathrm{U} / \mathrm{g} \mathrm{cr}$, and $\mathrm{U} \beta_{2}$-MG changed from 4.09 to $2965.66 \mu \mathrm{g} / \mathrm{g}$ cr.

The geometric mean for the female UCd level $(4.522 \mu \mathrm{g} / \mathrm{g} \mathrm{cr})$ was higher than that for the males $(4.483 \mu \mathrm{g} / \mathrm{g}$ cr $) \quad(p<0.05)$ (Table 2). Per clinical standards, patients are termed at risk if their UCd levels are higher than $5.000 \mu \mathrm{g} / \mathrm{g} \mathrm{cr}$. In our study, the median UCd value for both male or female participants was higher than the national standard threshold value $(5 \mu \mathrm{g} / \mathrm{g} \mathrm{cr})$ recommended by GOMOHC in 2010 [31].

Additionally, for high UCd concentration level, more than $5 \%$ of male $(12.263 \mu \mathrm{g} / \mathrm{g} \mathrm{cr})$ was found lower than of female $(13.520 \mu \mathrm{g} / \mathrm{g} \mathrm{cr})$. It was found that the UCd for $53.79 \%$ of all participants had high values, meaning that half of the sample was at risk of high $\mathrm{Cd}$ exposure. The mean UCd values for those aged $80-90$ years old were 2.5 the national threshold standard. The likelihood of high UCd increased with age $(p<0.001)$ (Table 2$)$. The mean UNAG $(22.433 \mathrm{U} / \mathrm{g} \mathrm{cr})$ was far above the national threshold value of $17 \mathrm{U} / \mathrm{g}$ cr, as was the mean $\mathrm{U} \beta_{2}$-MG $(2122.665 \mu \mathrm{g} / \mathrm{g} \mathrm{cr})$ in relation to the national threshold value of $1000 \mu \mathrm{g} / \mathrm{g} \mathrm{cr}$ ). The 75th to 95th percentiles for UNAG (20.661-33.271 U/ $\mathrm{g} \mathrm{cr})$ and $\mathrm{U} \beta_{2}$-MG $(1176.22-1834.13 \mu \mathrm{g} / \mathrm{g} \mathrm{cr})$ concentrations were likewise high.

\section{Relationship between urinary cadmium burden and renal dysfunction index}

Index UNAG and $\mathrm{U} \beta_{2}$-MG were outlined. The percentage of high UNAG among female participants was $32.34 \%$, and among males, it was $26.58 \%$ (Table 3 ). The percentages were higher for $\mathrm{U} \beta_{2}$-MG, with $41.77 \%$ for females and $36.63 \%$ for males. Thus, a trend of elevated values in UCd levels and the indexes is mentioned above. The rate of abnormal UNAG among males was $53.49 \%$, and that of females was $61.44 \%$ (Table 3). The $\mathrm{U} \beta_{2}$-MG values ranged from 17.44 to $67.44 \%$ among makes and from 20.41 to $71.90 \%$ among. $\mathrm{U} \beta_{2}$-MG was more sensitive than UNAG $(p<0.05)$, supported previous results that $\mathrm{U} \beta_{2}$-MG might be a more sensitive biomarker than UNAG for $\mathrm{Cd}$ exposure risk [32]. Moreover, the odds of UNAG and $\mathrm{U} \beta_{2}$-MG increased linearly with UCd levels $(p<0.01)$. A further $x^{2}$ test of the linear trend verified that the indexes related to UCd levels $(p<0.01)$. An interesting finding was that the relationship of index response to renal dysfunction in females was higher than in males for the same UCd burden (Table 3).

A linear regression indicated a positive correlation between age and UCd $(p<0.05)$ (Table 4). The correlation coefficient of the $\mathrm{U} \beta_{2}-\mathrm{MG}$ level was higher than of UNAG $(p<0.05)$. Furthermore, the positive correlations between UCd and age, gender, UNAG, and $\mathrm{U} \beta_{2}-\mathrm{MG}$ were validated using Pearson correlation analysis $(p<$ $0.05)$, but no significant correlation was found for village site $(p>0.05)$ (Table 4$)$. A positive correlation between UNAG and U $\beta_{2}$-MG was also confirmed $(p<0.01)$.

The renal indicators UNAG and $\mathrm{U} \beta_{2}$-MG were considered to be dependent variables, and the age, sex, region, and UCd levels (statistically analyzed after logarithmic transformation obeying the normal distribution) were considered to be independent variables. The variables that were entered into the regression (age, $\mathrm{UCd}$, UNAG, and $\mathrm{U} \beta_{2}-\mathrm{MG}$ ) were subjected to multiple linear regression analyses based on linear regression analysis. Certain factors, such as age, sex, and environmental exposure, may have resulted in a misleading assessment of the relationship between UCd burden and renal indexes. A step-by-step linear regression analysis, found $\beta^{\prime}$ values for UNAG and U $\beta_{2}$-MG of 0.459 and 0.493 , respectively (Table 5). It was also found that UNAG and

Table 2 Comparison of UCd concentrations and prevalence of UCd in population with different demographic characteristics

\begin{tabular}{|c|c|c|c|c|c|c|c|}
\hline Characteristics & No. & Mean (GSD) & $\mathrm{P}_{50}\left(\mathrm{P}_{25 \sim 75}\right)$ & $P_{95}$ & Abnormal number & $x^{2}$ & $P$ \\
\hline & & & & & [Percentage(\%)] & & \\
\hline Gender & & & & & & 0.302 & $<0.05$ \\
\hline Male & 587 & $4.483(3.786)$ & $5.751(2.463 \sim 8.077)$ & 12.263 & $328(55.88)$ & & \\
\hline Female & 1008 & $4.522(3.896)$ & $5.700(3.542 \sim 8.156)$ & 13.520 & $530(52.58)$ & & \\
\hline Age & & & & & & 747.000 & $<0.001$ \\
\hline $50 \sim$ & 589 & $4.401(3.657)$ & $5.576(2.471 \sim 7.935)$ & 12.105 & $302(51.27)$ & & \\
\hline $60 \sim$ & 687 & $4.494(3.833)$ & $5.775(3.544 \sim 8.230)$ & 12.399 & $367(53.42)$ & & \\
\hline $70 \sim$ & 257 & $4.671(4.127)$ & $5.803(3.585 \sim 8.213)$ & 14.937 & 143(55.64) & & \\
\hline $80 \sim$ & 62 & $5.038(4.558)$ & $6.009(2.412 \sim 9.830)$ & 17.398 & $35(56.45)$ & & \\
\hline
\end{tabular}

The units of the above indicators: Abnormal number (person), UCd ( $\mu \mathrm{g} / \mathrm{g} \mathrm{cr}$ ), GSD (Geometric Standard Deviation). $5 \mu \mathrm{g} / \mathrm{g} \mathrm{cr}$ is the criterion for determining abnormality of UCd 
Table 3 Prevalence of renal dysfunction at different UCd levels in male and female

\begin{tabular}{|c|c|c|c|c|c|c|c|c|c|c|}
\hline \multirow[t]{2}{*}{$\overline{\mathrm{UCd}}$} & \multicolumn{5}{|c|}{ Male } & \multicolumn{5}{|c|}{ Female } \\
\hline & No. & UNAG +/- & $\%$ & $U \beta_{2}-M G+/-$ & $\%$ & No. & UNAG +/- & $\%$ & $U \beta_{2}-M G+/-$ & $\%$ \\
\hline$(0 \sim 2]$ & 86 & $5 / 81$ & 5.81 & $15 / 71$ & 17.44 & 147 & $12 / 135$ & 8.16 & $30 / 117$ & 20.41 \\
\hline$(2 \sim 5]$ & 173 & $34 / 139$ & 19.65 & $45 / 128$ & 26.01 & 331 & $68 / 263$ & 20.54 & $93 / 238$ & 28.10 \\
\hline$(5 \sim 10]$ & 242 & $71 / 171$ & 29.34 & $97 / 145$ & 40.08 & 377 & $152 / 225$ & 40.32 & 188/189 & 49.87 \\
\hline$(10 \sim$ & 86 & $46 / 40$ & 53.49 & $58 / 28$ & 67.44 & 153 & $94 / 59$ & 61.44 & $110 / 43$ & 71.90 \\
\hline Total & 587 & $156 / 431$ & 26.58 & $215 / 372$ & 36.63 & 1008 & $326 / 682$ & 32.34 & $421 / 587$ & 41.77 \\
\hline$x^{2}$ & & 56.115 & & 58.462 & & & 130.485 & & 156.434 & \\
\hline$p$ & & 0.000 & & 0.000 & & & 0.000 & & 0.000 & \\
\hline Linear- $X^{2}$ & & 52.520 & & 53.353 & & & 128.313 & & 154.094 & \\
\hline$p$ & & 0.000 & & 0.000 & & & 0.000 & & 0.000 & \\
\hline
\end{tabular}

The units of the above indicators: UCd $\left(\mu \mathrm{g} / \mathrm{g} \mathrm{cr}\right.$ ), UNAG (U/g cr), U $\beta_{2}-\mathrm{MG}(\mu \mathrm{g} / \mathrm{g} \mathrm{cr})$. Chi-squared linear trend test, $p<0.01 .5 \mu \mathrm{g} / \mathrm{g} \mathrm{cr}$ is the criterion for determining abnormality of UCd. $17 \mathrm{U} / \mathrm{g}$ cr is the criterion for determining abnormality of UNAG. $1000 \mu \mathrm{g} / \mathrm{g} \mathrm{cr}$ is the criterion for determining abnormality of $U \beta_{2}-M G$

$\mathrm{U} \beta_{2}$-MG were sensitive biomarkers, and both may serve as primary indexes for BMD calculations.

\section{BMD of UCd for UNAG and $U \beta_{2}-M G$}

The optimized logistic model was selected when fitting UNAG or $\mathrm{U}_{2}$-MG. The BMD of UCd was presented and grouped according to gender (Table 6). The BMR was set at $10 \%$, and UNAG was employed. BMD and BMDL for male UCd were nearly $3.876 \mathrm{U} / \mathrm{g}$ cr and $3.486 \mathrm{U} / \mathrm{g}$ cr, respectively. For the same parameter, the BMD and BMDL for female UCd were $3.236 \mathrm{U} / \mathrm{g}$ cr and $2.998 \mathrm{U} / \mathrm{g} \mathrm{cr}$, respectively. Given the same parameters for $\mathrm{U} \beta_{2}-\mathrm{MG}$, the BMD and BMDL for male UCd were nearly $2.784 \mu \mathrm{g} / \mathrm{g}$ cr and $2.506 \mu \mathrm{g} / \mathrm{g} \mathrm{cr}$, respectively, and the BMD and BMDL of female UCd were about $2.416 \mu \mathrm{g} / \mathrm{g}$ cr and $2.236 \mu \mathrm{g} / \mathrm{g} \mathrm{cr}$, respectively (Table 6). This indicates that the BMDL of female UCd was lower than that of the male, implying that females were more vulnerable than males for the same UCd burden.

Based on the previous research, more study of the precise indexes was performed. In order to ensure the completeness and representativeness of the experimental results, all the dichotomous models for BMDs were applied, with BMR set as $15,20,25$, and $30 \%$. The national standard $(5 \mu \mathrm{g} / \mathrm{g} \mathrm{cr})$ was produced by setting BMR to

Table 4 Pearson's correlation coefficients of factors affecting UCd and renal dysfunction

\begin{tabular}{llllll}
\hline Index & Gender & Village & UNAG & U $\beta_{2}-M G$ & UCd \\
\hline Age & $0.101^{\mathrm{b}}$ & 0.001 & 0.035 & 0.04 & $0.055^{\mathrm{a}}$ \\
Gender & - & -0.005 & -0.003 & -0.027 & $0.076^{\mathrm{a}}$ \\
Village & - & - & 0.027 & 0.044 & 0.033 \\
UNAG & - & - & - & $0.258^{\mathrm{b}}$ & $0.437^{\mathrm{b}}$ \\
U $\beta_{2}-\mathrm{MG}$ & - & - & - & - & $0.492^{\mathrm{b}}$ \\
\hline
\end{tabular}

${ }^{a}$ : Correlation is significant at the 0.05 level (two-tailed); ${ }^{\text {b }}$ : Correlation is significant at the 0.01 level (two-tailed). UCd, UNAG and U $\beta_{2}-M G$ were logtransformed for correlation analysis
$20 \%$. To protect people's health from high levels of $\mathrm{Cd}$ exposure, additional restrictions to the sensitivity index and BMD should be considered.

\section{Discussion}

Exposure to excess Cd may pose health risks [33, 34]. Clinically ascertaining threshold concentrations of UCd is greatly important and aids understanding of the health risks. Sensitivity indexes for the UCd burden have been a topic of wide concerned $[15,21]$. In response to our questionnaire, more than $50 \%$ of respondents indicated their awareness of suffering high Cd exposure for a certain time. The results of a preliminary investigation of UCd levels and sensitivity biomarkers are discussed here.

In our study, UCd values for females varied from $0.030 \mu \mathrm{g} / \mathrm{g}$ cr to $20.279 \mu \mathrm{g} / \mathrm{g} \mathrm{cr}$, higher than those found in past research, which has suggested the UCd levels in females ranged from 0.49 to $0.69 \mu \mathrm{g} / \mathrm{g} \mathrm{cr}$, as deduced from individuals aged 50-79 in the US [35]. It has been speculated that age is a factor that determines UCd

Table 5 Results of multiple linear regression analysis of factors affecting UCd levels and renal dysfunction

\begin{tabular}{llllll}
\hline Variable & $\beta(95 \% \mathrm{Cl})$ & $\mathrm{S}_{x}^{-}$ & $\beta^{\prime}$ & $\mathrm{t}$ & $\mathrm{p}$ \\
\hline UNAG & & & & & \\
Age & $0.021(-0.028 \sim 0.071)$ & 0.025 & 0.019 & 0.843 & 0.399 \\
UCd & $1.130(1.023 \sim 1.238)$ & 0.055 & 0.459 & 20.600 & 0.000 \\
U $\beta_{2}-\mathrm{MG}$ & $0.001(0.000 \sim 0.002)$ & 0.000 & 0.052 & 2.099 & 0.036 \\
U $\beta_{2}-\mathrm{MG}$ & & & & & \\
Age & $1.728(-1.177 \sim 4.632)$ & 1.481 & 0.027 & 1.167 & 0.243 \\
UCd & $55.778(48.657 \sim 62.899)$ & 3.630 & 0.493 & 15.364 & 0.000 \\
UNAG & $3.095(0.203 \sim 5.986)$ & 1.474 & 0.054 & 2.099 & 0.036 \\
UCd & & & & & \\
Age & $0.031(2.437 \sim 5.399)$ & 0.011 & 0.067 & 2.666 & 0.008
\end{tabular}

$\beta$ partial regression coefficient; $S^{-}{ }_{x}$ standard error; $\beta^{\prime}$ standardized partial regression coefficient; $t \mathrm{t}$ value of T-test; $p p$ value 
Table 6 The BMDLs results of the UCd for UNAG and U $\beta_{2}-M G$ in male and female

\begin{tabular}{llllllll}
\hline Gender & Model Name & Dependent variable & AIC & Chi-square & P-value & BMD & BMDL \\
\hline Male & Logistic & UNAG & 629.41 & 3.66 & 0.16 & 3.876 & 3.486 \\
Female & Logistic & UNAG & 1141.52 & 5.50 & 0.06 & 3.236 & 2.998 \\
Male & Logistic & U $\beta_{2}-M G$ & 716.38 & 0.02 & 0.99 & 2.784 \\
Female & Logistic & U $\beta_{2}-M G$ & 1251.34 & 1.06 & 0.59 & 2.416 & 2.236 \\
\hline
\end{tabular}

The units: UNAG $(\mathrm{U} / \mathrm{g} \mathrm{cr}), \mathrm{U} \beta_{2}-\mathrm{MG}(\mu \mathrm{g} / \mathrm{g} \mathrm{cr})$

levels [36], and this is validated here. We found that UCd levels in the population increased with age (Table 1).

Additionally, UCd levels were affected by gender. The mean UCd among females differed statistically significantly from that of males (Table 2). The odd number of female UCd was 1.62 times higher than that of male $(p<0.05)$ (Table 3). This indicates that the females had accumulated more UCd, perhaps due to increased mineral retention and increased consumption of $\mathrm{Cd}$ contaminating food during pregnancy [37]. Recent work has shown that lower iron content in females than in males may be due to their different physiologies, which may allow for greater absorption of $\mathrm{Cd}$ by the female gastrointestinal tract [38, 39]. The suggestion in this study that females may be more sensitive to $\mathrm{Cd}$-induced nephrotoxicity than males supports an earlier study [40, 41].

Although mean levels of UCd and renal dysfunction were different for all age groups, an obvious dose-response relationship existed between $\mathrm{UCd}$ and the odds of renal dysfunction. This indicates that $\mathrm{Cd}$ exposure can cause irreversible damage to the kidney [21, 42]. For average UCd level, the odds of female were lower than that of males (Table 2); the reason might come from the sample sizes. Moreover, it has been found that endogenous hormones contribute to the UCd burden [43, 44]. The participants in our survey were all native residents, and most had been living in the study site more than 25 years. Long-term $\mathrm{Cd}$ exposure has been reported, and renal dysfunction has already been proven $[45,46]$. $U \beta_{2}$ MG and UNAG are in use as biomarkers for clinical diagnosis [15, 21] and animal experiments [47, 48]. In the later stages of $\mathrm{Cd}$-induced renal injury, the tubular epithelial cells may shrink, fall off, and even disappear, and the tissue source of UNAG is lost $[49,50]$. The reabsorption function of the kidney is impaired when UNAG was released, and the excretion of $U \beta_{2}-M G$ may be greater than that of UNAG [51, 52], which may be why $\mathrm{U} \beta_{2}$-MG produces higher values than UNAG in biological monitoring. In addition, the correlation coefficients for $\mathrm{U} \beta_{2}-\mathrm{MG}$ affecting $\mathrm{UCd}$ were higher than those for UNAG (Table 4). Traditionally, $U \beta_{2}-\mathrm{MG}$ could be more sensitive as a renal health effect indicator than UNAG.
A comparison of the threshold concentration of UNAG and $U \beta_{2}$-MG is essential for assessing the BMD of UCd using index total protein, UNAG, and $U \beta_{2}-\mathrm{MG}$ in non-occupationally endangered people [21, 53], and the relationship between the UCd burden and renal indexes was found to be statistically significant $(p<0.01)$, as cross-checked by different models.

It has been suggested that the accumulation and excretion of UNAG and $\mathrm{U} \beta_{2}-\mathrm{MG}$ increases significantly with the increase of $\mathrm{Cd}$ burden in the organism, and irreversible kidney damage becomes more serious as $\mathrm{Cd}$ exposure grows $[52,53]$.

In this study, subjects of different genders were divided into four groups according to UCd levels ( 0 to 2, 2 to 5, 5 to 10 , and $>10 \mu \mathrm{g} / \mathrm{g} \mathrm{cr}$ ). The results for BMDs showed that odd had a significant dose-effect trend with the selected effects endpoint. UNAG and $\mathrm{U} \beta_{2}-\mathrm{MG}$ were found to have good fit to the logistic model through BMD calculation.

The BMDLs of UCd for UNAG and $U \beta_{2}-M G$ in females were lower than those for males according to the BMDs results (Table 6), which also indicated that females were more sensitive to $\mathrm{Cd}$ exposure than males.

To protect human health from the high $\mathrm{Cd}$ burden, greater restrictions on sensitivity biomarkers and the BMD should be considered. BMD values of UCd for different renal indexes were lower than the standard threshold (5 $\mu \mathrm{g} / \mathrm{g} \mathrm{cr}$ ) (Table 6). More than $20 \%$ of people might be at risk for $\mathrm{Cd}$ exposure where the UCd level was around the national standard threshold value $(5 \mu \mathrm{g} /$ g cr) for BMR was 20\% (Table 7). Following our results, we recommend a value of $2.2 \mu \mathrm{g} / \mathrm{g} \mathrm{cr}$.

\section{Conclusions}

This study found that most participants at a Cdcontaminated site had suffered severe damage to their kidney function, and more than $50 \%$ were in a high-risk group for $\mathrm{Cd}$ pollution. Their UCd levels were significantly lower than the threshold suggested by World Health Organization and GOMOHC. $U \beta_{2}-\mathrm{MG}$ is recommended as the sensitivity index for renal dysfunction, with $2.2 \mu \mathrm{g} / \mathrm{g}$ cr as the threshold for clinical diagnosis. Our findings suggest that $U \beta_{2}-M G$ is the better biomarker for exposure to $\mathrm{Cd}$. Our findings provide a tool for understanding $\mathrm{Cd}$ exposure on large spatial scales, 
Table 7 The BMDLs of the UCd based on different BMRs in male and female

\begin{tabular}{|c|c|c|c|c|c|c|c|c|c|c|}
\hline Gender & $\begin{array}{l}\text { Model } \\
\text { Name }\end{array}$ & $\begin{array}{l}\text { Dependent } \\
\text { variable }\end{array}$ & $\begin{array}{l}\text { BMD } \\
(\mathrm{BMR}=15 \%)\end{array}$ & $\begin{array}{l}\mathrm{BMD} \\
(\mathrm{BMR}=15 \%)\end{array}$ & $\begin{array}{l}\text { BMD } \\
(\mathrm{BMR}=20 \%)\end{array}$ & $\begin{array}{l}\text { BMDL } \\
(\text { BMR = 20\%) }\end{array}$ & $\begin{array}{l}\text { BMD } \\
(\mathrm{BMR}=25 \%)\end{array}$ & $\begin{array}{l}\text { BMDL } \\
(\mathrm{BMR}=25 \%)\end{array}$ & $\begin{array}{l}\mathrm{BMD} \\
(\mathrm{BMR}=30 \%)\end{array}$ & $\begin{array}{l}\mathrm{BMDL} \\
(\mathrm{BMR}=30 \%)\end{array}$ \\
\hline Male & Logistic & UNAG & 5.251 & 4.740 & 6.447 & 5.818 & 7.526 & 6.777 & 8.527 & 7.656 \\
\hline Female & Logistic & UNAG & 4.138 & 3.858 & 5.131 & 4.793 & 6.037 & 5.641 & 6.885 & 6.427 \\
\hline Male & Logistic & $U \beta_{2}-M G$ & 3.909 & 3.525 & 4.934 & 4.446 & 5.890 & 5.296 & 6.798 & 6.097 \\
\hline Female & Logistic & $U \beta_{2}-M G$ & 3.423 & 3.174 & 4.350 & 4.034 & 5.222 & 4.838 & 6.058 & 5.604 \\
\hline
\end{tabular}

The units: UNAG $(\mathrm{U} / \mathrm{g} \mathrm{cr}), \mathrm{U} \beta_{2}-\mathrm{MG}(\mu \mathrm{g} / \mathrm{g} \mathrm{cr})$.

which could help assess the health risks of Cd burden. This study also deduced threshold UCd levels, which will support improved clinical diagnosis of $\mathrm{Cd}$ exposure.

\author{
Abbreviations \\ UCd: Urinary cadmium; UNAG: Urinary N-acetyl- $\beta$-D-glucosidase; U $\beta_{2-}$ \\ MG: Urinary $\beta_{2}$-microglobulin; BMD: Benchmark dose; BMR: Benchmark dose \\ response; BMDL: Benchmark dose low; BMDLs: Lower confidence limits; \\ NOAEL: No observed adverse effect level; AIC: Akaike information criterion; \\ GOMOHC: Guidelines for the Diagnosis and Treatment of Heavy Metal \\ Pollution of China in 2010; MOHC: Minister of Health of the People's \\ Republic of China
}

\section{Acknowledgements}

We are profoundly grateful to the study subjects for their assistance.

\section{Authors' contributions}

S.K. and HM.W. designed the study. J.Y., Q.Y., and HG.H. collected the data. LS.Z. and T.T. analyzed the data. YT.L. and HM.W. wrote the paper. XL.P. and S.Y. contributed to the discussion and reviewed and edited the paper. All of the authors have given approval to the final text.

\section{Funding}

UCd assessment was funded by the Special Funds of the State Environmental Protection Public Welfare Industry, MEPC, with additional support from National Key Research and Development Program. UCd assessment was initiated, conducted, and interpreted independently of the principal study funder (MEPC).

\section{Availability of data and materials}

The datasets used and/or analyzed during the current study are available on request from the corresponding author.

\section{Ethics approval and consent to participate}

Questionnaires were administered on the status that informed consents were signed. This study was approved by the Ethics Committee of the School of Science, Beijing Jiaotong University and the No. 1 People's Hospital of Xiaogan. After informed consents were obtained from subjects, this survey was carried out by uniformly trained investigators.

\section{Consent for publication}

Not applicable.

\section{Competing interests}

The authors declare that they have no competing interests.

Received: 19 December 2019 Accepted: 23 August 2020

Published online: 05 September 2020

\section{References}

1. Keiko A. Itai-itai disease: lessons from the investigations of environmental epidemiology conducted in the 1970's, with special reference to the studies of the Toyama institute of health. J Hyg. 2017;72(3):149-58

2. Lee DW, Oh SH, Park MK, Lim YH, Hong YC. Environmental cadmium exposure is associated with elevated risk of chronic otitis media in adults. Occup Environ Med. 2018;75(7):515-21.
3. Aleksandra B, Vesna M, Biliana A, Zorica B, Marijana C, Elisavet R, Aristidis T, Amie S, David W. Overview of cadmium thyroid disrupting effects and mechanisms. Int J Mol Sci. 2018;19(5):1501-19.

4. Engström A, Michaëlsson K, Suwazono Y. Long-term cadmium exposure and the association with bone mineral density and fractures in a population-based study among women. J Bone Miner Res. 2015;26(3):48695.

5. LV Y, Wang P, Huang R, Liang X, Wang P, Tan J, Chen Z, Dun Z, Wang J, Jiang QJ. Cadmium exposure and osteoporosis: a population-based study and benchmark dose estimation in southern China. J Bone Miner Res. 2017; 32(10):1990-2000

6. Eriksen KT, Mcelroy JA, Harrington JM, Levine KE, Pedersen C. Sã, Rensen M, Tjã , Nneland a, Meliker JR, Raaschou-Nielsen OJ. Urinary cadmium and breast Cancer: a prospective Danish cohort study. J Natl Cancer Inst. 2017:109(2):1-7.

7. Djordjevic VR, Wallace DR, Schweitzer A, Boricic N. Environmental cadmium exposure and pancreatic cancer: evidence from case control, animal and in vitro studies. Environ Int. 2019;128:353-61.

8. Thijssen S, Lambrichts I, Maringwa J, Van KE. Changes in expression of fibrotic markers and histopathological alterations in kidneys of mice chronically exposed to low and high cd doses. J Toxicology. 2007;238(2): 200-10.

9. Renugadevi J, Prabu SM. Naringenin protects against cadmium-induced oxidative renal dysfunction in rats. J Toxicology. 2009;256(1):128-34.

10. Eom SY, Seo MN, Lee YS, Park KS, Hong YS, Sohn SJ, Kim YD, Choi BS, Lim JA, Kwon HJ. Low-level environmental cadmium exposure induces kidney tubule damage in the general population of Korean adults. Arch Environ Con Tox. 2017;73(3):401-9.

11. Luo T, Liu G, Long M, Yang J, Song R, Wang Y, Yuan Y, Bian J, Liu X, Gu J. Treatment of cadmium-induced renal oxidative damage in rats by administration of alpha-lipoic acid. Environ Sci Pollut R. 2017;24(2):1832-44

12. Nordberg G, Jin T, Wu X, Lu J, Chen L, Liang Y, Lei L, Hong F, Bergdahl IA, Nordberg MJ. Kidney dysfunction and cadmium exposure-factors influencing dose-response relationships. J Trace Elem Med Bio. 2012;26(23):197-200

13. Gao Y, Lu Y, Huang S, Gao L, Liang X, Wu Y, Wang J, Huang Q, Tang L, Wang $G$. Identifying early urinary metabolic changes with long-term environmental exposure to cadmium by mass-spectrometry-based metabolomics. J ES T. 2014:48(11):6409-18.

14. Wu H, Liao Q, Chillrud SN, Yang Q, Huang L, Bi J, Yan B. Environmental exposure to cadmium: health risk assessment and its associations with hypertension and impaired kidney function. Sci Rep. 2016;6:29989.

15. Duc PH, Kido T, Dung MH, Thai AL, Phuong Oanh NT, Okamoto R, Ichimori A, Nogawa K, Suwazono Y, Nakagawa HJ. A 28-year observational study of urinary cadmium and $\beta_{2}$-microglobulin concentrations in inhabitants in cadmium-polluted areas in Japan. J Appl Toxicol. 2016;36(12):1622-8.

16. Ratelle M, Li X, Laird BD. Cadmium exposure in first nations communities of the Northwest Territories, Canada: smoking is a greater contributor than consumption of cadmium-accumulating organ meats. Environ Sci-Proc Imp. 2018;20(10):1039-73.

17. Mesquita SR, Ergen ŞF, Rodrigues AP, Oliva-Teles MT, Delerue-Matos C, Guimarães L. N-acetyl- $\beta$-d-glucosaminidase activity in feral Carcinus maenas exposed to cadmium. Aquat Toxicol. 2015;159:225-32.

18. Liu CX, Li YB, Zhu CS, Dong ZM, Zhang K, Zhao YB, Xu YL. Benchmark dose for cadmium exposure and elevated $\mathrm{N}$-acetyl- $\beta$-d-glucosaminidase: a metaanalysis. Environ Sci Pollut Res. 2016;23:20528-38.

19. Chen X, Dai Y, Wang Z, Zhu G, Ding X, Jin TJ. The association between serum vitamin $D$ levels and renal tubular dysfunction in a general population exposed to cadmium in China. J Pone. 2018;13(4):195682-11. 
20. Phuc HD, Kido T, Oanh NT, Manh HD, Anh LT, Oyama Y, Okamoto R, Ichimori A, Nogawa K, Suwazono YJ. Effects of aging on cadmium concentrations and renal dysfunction in inhabitants in cadmium-polluted regions in Japan. J Appl Toxicol. 2017;37(12):3455-64.

21. Satarug S, Ruangyuttikarn W, Nishijo M, Ruiz PJ. Urinary cadmium threshold to prevent kidney disease development. Toxics. 2018;6(2):26-39.

22. Woo HD, Chiu WA, Jo S, Kim J. Benchmark dose for urinary cadmium based on a marker of renal dysfunction: a meta-analysis. J Pone. 2015;10(5): 126680-12

23. Hu J, Li M, Han TX, Chen JW, Ye LX, Wang Q, Zhou YK. Benchmark dose estimation for cadmium-induced renal tubular damage among environmental cadmium-exposed women aged $35-54$ years in two counties of China. J Pone. 2014;9(12):115794-14.

24. Nishijo M, Suwazono Y, Ruangyuttikarn W, Nambunmee K, Swaddiwudhipong W, Nogawa K, Nakagawa H. Risk assessment for Thai population: benchmark dose of urinary and blood cadmium levels for renal effects by hybrid approach of inhabitants living in polluted and nonpolluted areas in Thailand. BMC PH. 2014;14(1):702-9.

25. Wang X, Wang Y, Feng L, Tong Y, Chen Z, Ying S, Chen T, Li T, Xia H, Jiang $Z$ Z. Application of the benchmark dose (BMD) method to identify thresholds of cadmium-induced renal effects in non-polluted areas in China. J Pone. 2016;11(8):161240-12.

26. Shen $\mathrm{KE}, \mathrm{Mei} \mathrm{KQ}$, Jing JW, et al. Benchmark dose estimation for cadmiuminduced renal effects based on a large sample population from five Chinese provinces [J]. Biomed Environ Sci. 2015;28(5):383-7.

27. Suwazono Y, Nogawa K, Morikawa Y, Nishijo M, Kobayashi E, Kido T, Nakagawa H, Nogawa KJ. Impact of urinary cadmium on mortality in the Japanese general population in cadmium non-polluted areas. JoH Health E. 2014;217(8):807-12.

28. MOHC. Standard of China. In: GB/T 17221-1998. Beijing: Standards Press of China; 1998.

29. Kippler M, Nermell B, Hamadani J, Tofail F, Moore S, Vahter M. Burden of cadmium in early childhood: longitudinal assessment of urinary cadmium in rural Bangladesh. Toxicol Lett. 2010;198(1):20-5.

30. Edler L. Benchmark dose in regulatory toxicology. Regulatory Toxicology. 2014;1:359-75.

31. Wang J, Chen CJETR. The current status of heavy metal pollution and treatment technology development in China. Environ Technol. 2015:4(1):39_ 53.

32. Kobayashi E, Suwazono Y, Uetani M, Inaba T, Oishi M, Kido T, Nishijo M, Nakagawa H, Nogawa K. Estimation of benchmark dose as the threshold levels of urinary cadmium, based on excretion of total protein, betamicroglobulin, and N-acetyl-beta-D-glucosaminidase in cadmium nonpolluted regions in Japan. Environ Res. 2006;101(3):401-6.

33. Qasemi M, Shams M, Sajjadi SA, Farhang M, Erfanpoor S, Yousefi M, Zarei A, Afsharnia M. Cadmium in groundwater consumed in the rural areas of Gonabad and Bajestan, Iran: Occurrence and Health Risk Assessment. Biol Trace Elem Res. 2019;11:1-10.

34. Nishijo M, Nakagawa H, Suwazono Y, Nogawa K, Sakurai M, Ishizaki M, Kido T. Cancer mortality in residents of the cadmium-polluted Jinzu River basin in Toyama. Japan Toxics. 2018;6(2):23-33.

35. Kim J, Garcia-Esquinas E, Navas-Acien A, Choi YH. Blood and urine cadmium concentrations and walking speed in middle-aged and older U.S. adults. Environ Pollut. 2017;22(9):1-8.

36. Peng Q, Bakulski KM, Nan B, Park SK. Cadmium and Alzheimer's disease mortality in U.S. adults: updated evidence with a urinary biomarker and extended follow-up time. Environ Res. 2017;157:44-51.

37. Ohta H, Ichikawa M, Seki Y. Effects of cadmium intake on bone metabolism of mothers during pregnancy and lactation. TJEM. 2002;196(1):33-42.

38. HarlalChoudhury TH, Thayer WC, Lockwood TF, Stiteler WM, Goodrum PE, Hassett JM, Diamond GL. Urinary cadmium elimination as a biomarker of exposure for evaluating a cadmium dietary exposure-biokinetics model. J Toxicol Env Heal A. 2001;63(5):321-50.

39. Gerda R, Maria K, Anna A, Rubhana R, Eva-Charlotte E, Staffan S, Marie V, Karin B. Polymorphisms in Iron homeostasis genes and urinary cadmium concentrations among nonsmoking women in Argentina and Bangladesh. Environ Health Persp. 2013;121(4):467-72.

40. Han J, Ji HU, Hong S, Jing Q, Wang X, Lou X, Zhen D, Chen X, Zhang W, Qi SJ. Investigation of urinary cadmium characteristics of the general population in three non-cadmium-polluted rural areas in China. J Hyg Res. 2014:43(6):939-45
41. Buha A, Jugdaohsingh $R$, Matovic V, Bulat Z. Bone mineral health relates to environmental cadmium exposure-experimental and human data. Environ Res. 2019;176:108539-11.

42. Ignjatović $\mathrm{NL}$, Janković R, Uskoković V, Uskoković DP. Effects of hydroxyapatite@poly-lactide-co-glycolide nanoparticles combined with Pb and cd on liver and kidney parenchyma after the reconstruction of mandibular bone defects. Toxicol Res. 2019;8(2):287-96.

43. Gollenberg AL, Hediger ML, Lee PA, Himes JH, Louis GM. Association between lead and cadmium and reproductive hormones in peripubertal $U$. S. girls. Environ Health Persp. 2010;118(12):1782-7.

44. Rosati MV, Montuori L, Caciari T, Sacco C, Marrocco M, Tomei G, Scala B, Sancini A, Anzelmo V, Bonomi SJ. Correlation between urinary cadmium and thyroid hormones in outdoor workers exposed to urban stressors. Toxicol Ind Health. 2015;32(12):1978-86.

45. Ming L, Li JZ, Ling T, Wei LJ. Ecophysiological responses of Jussiaea rapens to cadmium exposure. Aquat Bot. 2008;88(4):347-52.

46. Cai LM, Xu ZC, Qi JY, Feng ZZ, Xiang TS. Assessment of exposure to heavy metals and health risks among residents near Tonglushan mine in Hubei, China. Chemosphere. 2015;127:127-35.

47. Liang Y, Li H, Xiang C, Lei L, Jin T, Nordberg M, Nordberg GFJB, Pharmacology $C$. Increased hepatic and decreased urinary metallothionein in rats after cessation of oral cadmium exposure. Basic Clin Pharmacol. 2010; 106(4):348-55.

48. $Y Y X U$, Zhang $A H$, Jun $L I$, Chen $L Y$, Yao ML, Chun YU, Zeng QB, Jiang HE. Biomarkers in rats for kidney damage characteristics of arsenism due to coal burning and benchmark dose analysis. CJPT. 2014;28(2):243-7.

49. J MA, JH YI, X LI, WJ WU. Experimental study on the cytotoxicity in human proximal tubular epithelial cells by cadmium. JPMPH. 2010;21(4):15-8.

50. Kobayashi E, Suwazono Y, Dochi M, Honda R, Nishijo M, Kido T, Nakagawa H. Estimation of benchmark doses as threshold levels of urinary cadmium, based on excretion of $\beta_{2}$-microglobulin in cadmium-polluted and nonpolluted regions in Japan. Toxicol Lett. 2008;179(2):108-12.

51. Zhang YR, Wang P, Liang XX, Tan CS, Tan JB, Wang J, Huang Q, Huang R, Li $Z X$, Chen WC. Associations between urinary excretion of cadmium and renal biomarkers in nonsmoking females: a cross-sectional study in rura areas of South China. Int J Env Res Pub He. 2015;12(10):11988-2001.

52. Smith ER, Cai MM, Mcmahon LP, Wright DA, Holt SG. The value of simultaneous measurements of urinary albumin and total protein in proteinuric patients. Nephrol Dial Transpl. 2012;27(4):1534-41.

53. Nakajima M, Kobayashi E, Suwazono Y, Uetani M, Oishi M, Inaba T, Kido T, Shaikh ZA, Nogawa K. Excretion of urinary cadmium, copper, and zinc in cadmium-exposed and nonexposed subjects, with special reference to urinary excretion of $\beta_{2}$-microglobulin and metallothioneinand metallothionein. JBTER. 2005;108(1-3):17-31.

\section{Publisher's Note}

Springer Nature remains neutral with regard to jurisdictional claims in published maps and institutional affiliations.

Ready to submit your research? Choose BMC and benefit from:

- fast, convenient online submission

- thorough peer review by experienced researchers in your field

- rapid publication on acceptance

- support for research data, including large and complex data types

- gold Open Access which fosters wider collaboration and increased citations

- maximum visibility for your research: over $100 \mathrm{M}$ website views per year

At BMC, research is always in progress.

Learn more biomedcentral.com/submissions 